\title{
Fishing down Canadian aquatic food webs ${ }^{1}$
}

\author{
Daniel Pauly, Ma. Lourdes Palomares, Rainer Froese, Pascualita Sa-a, \\ Michael Vakily, David Preikshot, and Scott Wallace
}

\begin{abstract}
The mean trophic level (TL) of fish landed in fisheries on the east and west coasts of Canada is declining by $0.03-0.10 \cdot$ decade $^{-1}$, similar to global trends. This finding is based on data from United Nations Food and Agriculture Organization and the Canadian Department of Fisheries and Oceans and other Canadian sources for the period 1873-1997. Significant rates of decline in mean TL were obtained even when key species — Atlantic cod (Gadus morhua) on the east coast and Pacific herring (Clupea pallasi) and Pacific hake (Merluccius productus) on the west coast - were omitted from the analysis. Fish taken in inland water fisheries did not exhibit a decline in mean TL. Two models were developed, based on length and age, respectively, for correcting TL estimates of individual species for the effects of changes in body size due to changes in fishing mortality. Both produced corrections that were small relative to changes in mean TL that resulted from changes in species composition of the catch over time. Overall, these results suggest that the mean TL of fish landed can be used as an index of sustainability in multispecies fisheries and that its reliability will depend on the quality of the data and length of the time series available for analysis.
\end{abstract}

Résumé : Le niveau trophique (NT) moyen des poissons débarqués dans les pêches des côtes est et ouest du Canada baisse de 0,03 à 0,10 par décennie, comme c'est le cas dans les tendances mondiales. Ce constat se fonde sur des données de l'Organisation des Nations Unies pour l'alimentation et l'agriculture (FAO), du ministère des Pêches et des Océans du Canada et d'autres sources canadiennes, pour la période allant de 1873 à 1997. Des taux significatifs de déclin du NT moyen ont été obtenus même lorsque des espèces clés - morue franche sur la côte atlantique, hareng et merlu sur la côte pacifique - étaient omises dans l'analyse. Les poissons capturés dans les eaux intérieures ne présentaient pas de baisse du NT moyen. Deux modèles ont été construits, basés respectivement sur la longueur et sur l'âge, pour corriger les estimations du NT de chaque espèce de façon à tenir compte des effets des changements de la taille corporelle dus à des changements dans la mortalité par pêche. Les deux modèles ont produit des corrections qui étaient petites par rapport aux changements dans le NT moyen dus à des modifications de la composition spécifique des captures au fil du temps. Globalement, ces résultats permettent de penser que le NT moyen des poissons débarqués peut être utilisé comme un indice de durabilité dans les pêches plurispécifiques, et que sa fiabilité dépendra de la qualité des données et de la longueur des séries chronologiques disponibles pour les analyses.

[Traduit par la Rédaction]

\section{Introduction}

There is broad agreement in the literature that fisheries affect not only target and bycatch species but also the ecosystems in which these species are embedded (Parsons 1996; National Research Council 1999). The resulting calls for ecosystem-based management are more controversial. One

Received January 24, 2000. Accepted August 20, 2000. Published on the NRC Research Press web site on November 23, 2000. $\mathrm{J} 15541$

D. Pauly ${ }^{2,3}$ and D. Preikshot. Fisheries Centre, University of British Columbia, 2204 Main Mall, Vancouver, BC V6T 1Z4, Canada.

R. Froese, M. Lourdes Palomares, P. Sa-a, and M. Vakily. FishBase Project, International Center for Living Aquatic Resources Management (ICLARM), c/o IRRI, Los Baños College, Laguna, Philippines.

S. Wallace: School for Field Studies, Bamfield, BC V0R 1B0, Canada.

${ }^{1}$ Invited perpective for this 100th Anniversary Issue.

${ }^{2}$ Corresponding author.

${ }^{3}$ Present address: Fisheries Centre, University of British Columbia, 2204 Main Mall, Vancouver, BC V6T 1Z4, Canada (e-mail: d.pauly@ fisheries.ubc.ca). reason is because there is at present no consensus on possible ecosystem "reference points" analogous to those used for single-species management, such as maximum sustainable yield or $F_{0.1}$.

One recurrent feature of aquatic ecosystems exploited by modern fisheries is the tendency for the biomass of large, long-lived, often piscivorous species to decline more rapidly than that of smaller, shorter-lived, often zooplanktivorous species (Kirkwood et al. 1994; Jennings et al. 1997; National Research Council 1999), a feature related to the usually low natural mortality of the former group (Myers and Doyle 1983). Therefore, where fleets target both large and small fishes (or use unselective gear), the contribution of fishes from the lower part of the food web to the aggregate catches will tend to increase over time. This was confirmed by the recent demonstration of a decline in the mean trophic level (TL) of organisms (fishes and invertebrates) landed globally by fisheries (Pauly et al. 1998).

Thus, the mean TL of organisms in landings from a given ecosystem could be used to integrate a vast array of biological features pertaining to the species therein, and its continuous decline, if associated with stagnating or declining catches, interpreted as indicating lack of sustainability at the ecosystem level (because overall biological production is highest at low TL; Pauly and Christensen 1995). This agrees 
with Caddy (1998) who suggested that "multispecies reference points could be derived from ecological/food web models."

However, if it is to become accepted as an index of the impact of fisheries on ecosystems, mean TL will have to be shown to be applicable in a variety of national settings, with a wide range of underlying statistical data, resource types, and fisheries. Also, issues of model sensitivity must be addressed, notably regarding the within-species changes of TL due to the change in size composition caused by fishing. We present such an evaluation here based on the mean TL of organisms in the landings of fisheries on the east coast (Maritimes, Quebec, and Newfoundland-Labrador), on the west coast (British Columbia), and in inland waters (lakes and rivers) of Canada. Two new models are developed for the quantitative assessment of the effects of size changes on the estimation of mean TL values.

\section{Materials and methods}

\section{Catch/landings statistics}

\section{East coast}

The landings data used for the east coast of Canada cover the period 1950-1997 and were supplied by the Government of Canada to the Food and Agriculture Organization (FAO) of the United Nations (www.fao.org) (similar FAO data sets were used in association with other sources for the west coast and inland waters of Canada). This data set, comprising 72 statistical categories that range from species (50) to genera (10) and higher groups (12), consists mainly of reports by or to Canadian authorities. These data do not include all the catches of distant-water fleets based in Europe, which fished until the 1970s in what subsequently became the Canadian Exclusive Economic Zone. Key features of this data set are provided in Table 1.

\section{West coast}

Statistics from a variety of sources were used to estimate the catches of the commercial fishery in British Columbia from 1873 to 1996. FAO statistics commenced in 1950. Annual reports to Ottawa from the Inspector of Fisheries for British Columbia commenced in 1873 and were published in "Canada Sessional Papers" by the Dominion Bureau of Statistics from 1919 to 1970. From 1952, landings data were also published in "British Columbia Catch Statistics." For some species, review articles were available that summarize commercial landings and provide factors for conversion from nonmetric units (Table 2).

Recreational catch statistics (for salmon) started in 1953; estimates for other species such as lingcod (Ophiodon elongatus) and rockfish are included in the annual recreational surveys only from 1981. Aboriginal salmon catches have been recorded by the Canadian Department of Fisheries and Oceans (DFO) since 1951. Minimum estimates of aboriginal catches for 1873-1950 were derived from Argue et al. (1990) and from estimates of precontact seafood consumption by First Nations (Hewes 1973).

The series of mean TLs constructed from these data exhibited strong fluctuations. We identified the simplest set of piecewise polynomials that would adequately describe the data using the algorithm described in Hintze (1998).

\section{Inland waters}

The freshwater landings data used here included FAO statistics (1950-1997) complemented by records for 1917-1968 collected by the Dominion Bureau of Statistics in collaboration with federal and provincial fisheries departments, records for 1969-1974 collected by Statistics Canada, records for 1976-1989 collected by the DFO (available online: www.dfo-mpo.gc.ca/communic/statistics/stat_e.htm), and records for 1990-1997 collected by DFO Statistical Services, Ottawa.

For the inland waters data set, we excluded marine fishes caught in estuarine waters, notably Atlantic cod (Gadus morhua), Atlantic herring (Clupea harengus), and rainbow smelt (Osmerus mordax). Landings in the early twentieth century were reported as either raw or finished products and in imperial units, e.g., fresh, salted, or in oil, as barrels, cases, pounds, or hundredweights. Conversions to metric equivalents were performed using factors in the fisheries reports for 1947 and 1948 of the Dominion Bureau of Statistics. Species names from various sources had to be matched, as some species were not reported or were given different names in different years. The combined time series of inland water landings included only those species for which continuous data were available (Table 3).

\section{TLs}

The TL estimates used here all rely on diet composition data and on the equation

$$
\mathrm{TL}_{i}=1+\sum_{j=1}^{n} \mathrm{DC}_{i j} \mathrm{TL}_{j}
$$

where $i$ is the predator, $j$ the $n$th prey, and $\mathrm{DC}_{i j}$ is the diet composition, expressing the fractions of each $j$ in the diet of $i$. Assignment of TL starts with plants and detritus, both with a definitional TL value of 1 . Thus, a consumer eating $40 \%$ plants $(\mathrm{TL}=1)$ and $60 \%$ herbivores $(\mathrm{TL}=2)$ will have a TL of $1+(0.4 \times 1+0.6 \times 2)=2.6$.

The variance of the TL estimates from eq. 1 , referred to here as the omnivory index $(\mathrm{OI})$, is calculated from

$$
\mathrm{OI}_{i}=\sum_{j=1}^{n}\left(\mathrm{TL}_{j}-\mathrm{TL}_{\text {preys }}\right)^{2} \mathrm{DC}_{i j}
$$

where $\mathrm{TL}_{\text {preys }}$ is the average TL of the $n$ prey species of $i$ and the other terms are as defined in eq. 1. We also use the standard error of TL, defined as the square root of the corresponding OI, for the catch pyramids described below.

The $\mathrm{DC}_{i j}$ and $\mathrm{TL}_{j}$ used here were obtained from two related sources: (1) mass-balance trophic models of ecosystems of the east and west coasts of Canada or adjacent areas, constructed with the ECOPATH software (Christensen and Pauly 1992; www.ecopath. org), and (2) published, species-specific diet composition data (for the $\mathrm{DC}_{i j}$ ) and previous (ECOPATH-based) estimates of the corresponding $\mathrm{TL}_{j}$, as incorporated in the "Food items table" of FishBase (Froese and Pauly 1998).

TL estimates obtained using source 1 , pertaining to species or higher taxa, corresponded closely to independent estimates of TL assessed using stable isotope ratios of nitrogen from Prince William Sound, Alaska (Kline and Pauly 1998). Herein, use was made of the observation that for every link in a food chain, the concentration in animal tissues of the heavier isotope $\left({ }^{15} \mathrm{~N}\right)$ increases by a nearly constant percentage $(\approx 3.4 \%)$ relative to that of ${ }^{14} \mathrm{~N}$. This suggests that TL estimates based on source 2 should also be reliable. The TL estimates of major species are summarized in Tables 1-3. Details of these and TL estimates for the other species considered in our analyses are documented in FishBase (Froese and Pauly 1998, with updates on www.fishbase.org).

Mean TLs of organisms in fisheries landings were calculated for each year using

$$
\overline{\mathrm{TL}}_{k}=\sum_{i=1}^{m} Y_{i k} \mathrm{TL}_{i} / \sum_{i=1}^{m} Y_{i k}
$$

where $Y_{i k}$ is the landings of species $i$ in year $k$ and $\mathrm{TL}_{i}$ is its TL. 
Table 1. Key features of the data set used for analyzing Canadian east coast fisheries (1950-1997) ${ }^{a}$ (also see Fig. 3A).

\begin{tabular}{|c|c|}
\hline Group $^{b}$ & Groups/species included $(\mathrm{TL})^{c}$ \\
\hline Molluscs & $\begin{array}{l}\text { More than eight species of clams, mussels, oysters, quahogs, and scallops (2.1); northern shortfin } \\
\text { squid (3.2); longfin squid (3.3) }\end{array}$ \\
\hline Flatfishes & $\begin{array}{l}\text { American plaice and witch flounder (3.1); flatfish nei (3.2); winter flounder, yellowtail flounder, and } \\
\text { Greenland halibut (3.5); Atlantic halibut (4.5) }\end{array}$ \\
\hline Other invertebrates & 11 groups (about 30 species) from sea urchins and snow crabs $(2.3)^{d}$ to lobster $(2.6)^{e}$ \\
\hline Other fishes & 21 groups (about 100 species) from rainbow smelt (2.6) to swordfish (4.5) \\
\hline Gadoids (excluding cod) & $\begin{array}{l}\text { Atlantic tomcod (3.3); Greenland cod (3.5); red hake and haddock (3.6); saithe and roundnose grena- } \\
\text { dier (3.8); white hake and tusk (4.2); silver hake (4.3) }\end{array}$ \\
\hline Small & Herring (3.1); pelagic fishes nei (3.2); $\mathrm{m}$ \\
\hline Atlantic $\operatorname{cod}^{f}$ & $\mathrm{TL}=4.01$ (from Bundy et al. 2000) \\
\hline \multicolumn{2}{|c|}{$\begin{array}{l}{ }^{a} \text { Detailed spreadsheet available from first author; FAO catches are from FishBase (Froese and Pauly 1998; www.fao.org). } \\
{ }^{b} \text { Groups ranked by year at which } 50 \% \text { of cumulative landings occurred (with "most recent" group up) to emphasize species succession; weighted mean } \\
\text { L series based on individual species, not group means. } \\
{ }^{c} \text { Nei = FAO term for "not elsewhere identified"; details on TL estimates including sources of diet information and standard errors may be found in } \\
\text { ishBase (Froese and Pauly } 1998 \text {, with updates on www.fishbase.org) and in Bundy et al. (2000). } \\
{ }^{d} \text { TL estimate for } C \text {. opilio from diet composition data in Wieczorek and Hooper (1995) and mean prey TL in FishBase. } \\
{ }^{e} \text { TL estimate for } H \text {. americanus from diet composition data in Elner and Campbell (1987) and mean prey TL in FishBase. } \\
\left.{ }^{f} \text { von Bertalanffy growth parameters and mortality for cod: } L_{\infty}=130 \mathrm{~cm} \text { total length; } W_{\infty}=24400 \mathrm{~g} ; K=0.12 \cdot y e a r^{-1} \text { (May et al. } 1965\right) ; M=0.18 \cdot y e a r \\
\text { inhorn } 1975 \text { ). }\end{array}$} \\
\hline
\end{tabular}

Table 2. Key features of the data set used for analyzing Canadian west coast fisheries (1873-1996) ${ }^{a}$ (also see Fig. 3B).

\begin{tabular}{|c|c|c|c|}
\hline Group $^{b}$ & Groups/species included (TL) ${ }^{c}$ & Fishery & Data source $(\mathrm{s})$ \\
\hline $\begin{array}{l}\text { Miscellaneous } \\
\text { invertebrates }\end{array}$ & $\begin{array}{l}13 \text { groups (about } 30 \text { species) from bivalves } \\
\text { and sea urchins }(2.1) \text { to shrimps }(2.6)\end{array}$ & $\begin{array}{l}\text { Commercial and some } \\
\text { aquaculture (oysters) }\end{array}$ & Sessional papers; Elsey 1933 \\
\hline Hake & Merluccius productus & Commercial & DFO \\
\hline Small pelagics & $\begin{array}{l}\text { Pacific herring and pilchard (3.0); mackerel } \\
\text { (3.3) }\end{array}$ & Commercial & $\begin{array}{l}\text { 1884-1937: sessional papers; pilchard } \\
\text { (1938-1948): Culley 1971; herring } \\
\text { (1938-1950): Hourston } 1980\end{array}$ \\
\hline Other fishes & $\begin{array}{l}17 \text { groups (about } 100 \text { species) from smelts } \\
(3.0) \text { to halibut }(4.0) \text { and tuna }(4.2)\end{array}$ & Mainly commercial & $\begin{array}{l}\text { Sessional papers; Carrothers 1941; } \\
\text { Hart and McHugh 1944; Ketchen } \\
\text { 1986; Cass et al. 1990; Stocker } \\
1994\end{array}$ \\
\hline \multirow[t]{2}{*}{ Salmonids ${ }^{e}$} & $\begin{array}{l}\text { Coho, chinook, chum, pink, sockeye salmon, } \\
\text { and steelhead trout }(3.8)\end{array}$ & Commercial & $\begin{array}{l}\text { 1873-1982: Shepard et al. 1985; } \\
\text { Shepard and Argue 1989; 1983- } \\
\text { 1996: DFO }\end{array}$ \\
\hline & & Recreational & 1953-1994: DFO \\
\hline
\end{tabular}

${ }^{a}$ Extracted from detailed spreadsheet available from first and last authors.

${ }^{b}$ Groups ranked by year at which $50 \%$ of cumulative landings occurred (with most "recent" group up) to emphasize species succession; weighted mean TL series are based on individual series, not group means.

${ }^{c}$ Details on TL estimates including sources of diet information and standard errors may be found in FishBase (Froese and Pauly 1998, with updates on www.fishbase.org).

${ }^{d}$ Conversion from individual weights: harbour seal, $81 \mathrm{~kg}$ (Fisher 1952); northern fur seal skin, $160 \mathrm{~kg}$ (Jefferson et al. 1993 ); Steller sea lion, 535 kg (Schusterman 1981; Bigg 1988); humpback, 40 t; blue, 160 t; sei, 30 t; fin, 75; minke, 14 t; right, 80 t; gray, 35 t; sperm, 57 t; Baird's beaked whale, 12 t (Jefferson et al. 1993).

${ }^{e}$ Conversion from individual weights: coho and chum, $4.52 \mathrm{~kg}$; chinook, $9.05 \mathrm{~kg}$; pink, $1.81 \mathrm{~kg}$; sockeye, $2.71 \mathrm{~kg}$; steelhead trout, $4.52 \mathrm{~kg}$ (Argue et al. 1990).

\section{Catch pyramids}

The mean TLs estimated from eq. 3 are presented here as temporal trends and as "catch pyramids" that contrast the distribution of landings by TL at the start and end of the FAO time series of landings, i.e., 1950 and 1997. The approach used to construct the catch pyramids uses the standard errors of the $\mathrm{TL}_{i}$ to define triangular distributions (base of triangle $=$ mean TL of each group \pm 2 $\mathrm{SE})$ to assign group-specific catches to different TL classes.

\section{Changes of TLs}

Caddy et al. (1998), commenting on the "fishing down the food web" approach initially presented in Pauly et al. (1998), pointed out that the TLs of individuals of a given fish or invertebrate species will vary between populations and different periods and especially between different ontogenic stages.

We accommodated nonontogenic variability of TL by concentrating on diet composition data from Canadian ecosystems. How- 
Table 3. Key features of the data set used for analyzing Canadian inland water fisheries (1917-1997) ${ }^{a}$ (also see Fig. 3C).

\begin{tabular}{|c|c|}
\hline Group $^{b}$ & Species included $(\mathrm{TL})^{c}$ \\
\hline Other fish & $\begin{array}{l}\text { Pimephales promelas (2.1); Hiodon alosoides and Lepomis gibbosus (3.1); Ameiurus nebulosus and Acipenser } \\
\quad \text { fulvescens (3.3); Ambloplites rupestris (3.4); Anguilla rostrata (3.6); Lota lota (4.0) }\end{array}$ \\
\hline Sauger & Stizostedion canadense (4.0) \\
\hline Carp & Cyprinus carpio (2.2) \\
\hline Perch & Perca flavescens (3.4) \\
\hline Salmonids $^{d}$ & Salvelinus fontinalis (3.0); S. alpinus (4.4); S. namaycush (4.5) \\
\hline Pike & Esox lucius (4.5) \\
\hline Walleye & Stizostedion vitreum (4.5) \\
\hline Whitefish & Coregonus clupeaformis (2.9) \\
\hline
\end{tabular}

\footnotetext{
${ }^{a}$ Detailed spreadsheet available from first author.

${ }^{b}$ Grouped only for this table and Fig. 3C; weighted mean TL series based on landings and TL of individual species.

${ }^{c}$ Details on TL estimates and standard errors may be found on www.fishbase.org.

${ }^{d}$ Pacific salmon (especially coho and chinook) introduced into the Great Lakes and other freshwater bodies are not included, as biomasses (and hence landings) largely depend on continuous stocking.
}

Fig. 1. Relationship between TL estimates and body length $(\mathrm{cm})$ in 180 species of fishes. The regression lines (forced through the origin, representing larvae with $\mathrm{TL}=3$ and length $\approx 1 \mathrm{~cm}$ ) have slopes of $b_{a}=0.24$ for first-order carnivores (broken line and open circles, representing herring and other small pelagic and demersal fishes) and $b_{b}=0.63$ for higher-order carnivores (solid line and solid circles, representing cod-like and other large piscivorous demersal and pelagic fishes).

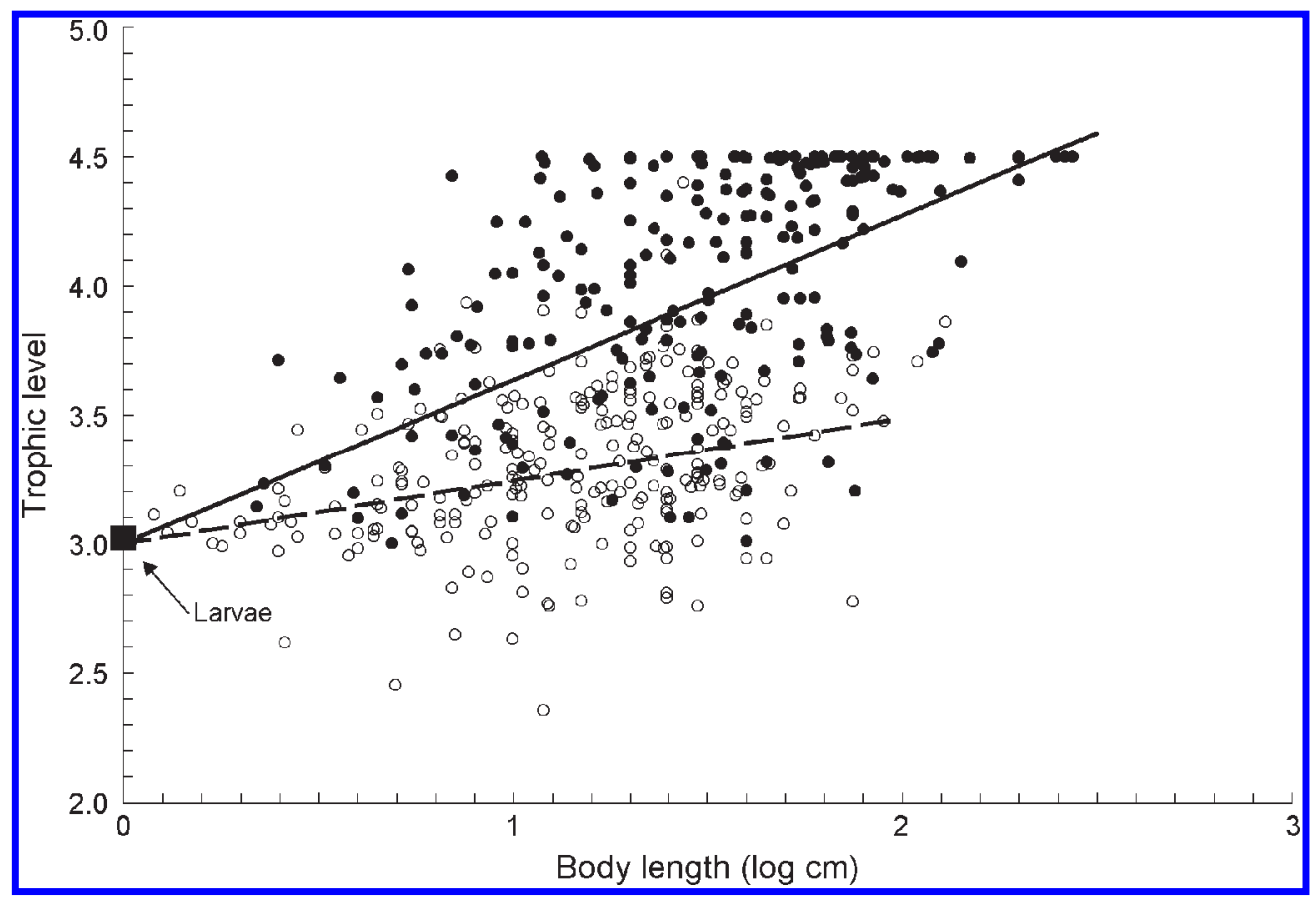

ever, we could not accommodate between-year variability of TL because suitable time series of diet composition could not be found. Moreover, we believe this form of variability to be small, e.g., a large piscivore cannot revert to feeding on herbivorous zooplankton when prey fishes are scarce. Indeed, feeding habits in fishes are largely a function of morphology and size (e.g., see De Groot 1981).

Ontogenic changes were accommodated by first documenting and quantifying general relationships between the TL and size of fishes. (Data were not available to document such relationships in invertebrates. Thus, we assume here that the TL of invertebrates does not change with fishing mortality. This assumption is briefly revisited in the Discussion.) This was done by first extracting from FishBase those species for which at least two TL values were available, of which one pertained to the adult stage. We found 180 species that met this criterion, represented by 578 TL estimates. In the absence of true herbivores among Canadian fishes, these species were then pooled into two sets: first-order carnivores, i.e., fishes whose adult TL ranges from 2.75 to 3.75 , close to the $T L=$ 3 typical of their larvae (which feed almost exclusively on herbivorous zooplankton), and higher-order carnivores, i.e., fishes whose adult TL reaches values higher than 3.75 (Froese and Pauly 1998; Cortés 1999).

Regression lines linking the TL estimates and the corresponding $(\log )$ length values of each group were then forced through the single point representing the larvae of both groups $(\mathrm{TL}=3$, length $=$ $1 \mathrm{~cm}$, i.e., log length $=0$ ) (Fig. 1). This leads to equations of the form

$$
\mathrm{TL}=3+b \log _{10}(L)
$$


where the slope $b$ expresses the change of TL with (log) body size, itself expressed in centimetres. This relationship generated relatively small differences of within-species mean TL when applied to observed length-frequency distributions of cod landings (Fig. 2). Nevertheless, we developed and tested two generic approaches length and age based, respectively — for quantifying the effect on mean TL of changes in the size composition of exploited populations as a result of increasing fishing mortality.

Length-based relationship between fishing mortality and TL

Beverton and Holt (1956) showed that total mortality $(Z)$ in fish populations whose individuals grow according to the von Bertalanffy growth function (VBGF) can be expressed by

$$
Z=\left[K\left(L_{\infty}-\bar{L}\right)\right] /\left(\bar{L}-L_{\mathrm{c}}\right)
$$

where $L_{\infty}$ is the asymptotic length, i.e., the mean size that the individuals in the population would reach if they were to live and grow indefinitely, $K$ is the rate at which $L_{\infty}$ is approached, and $\bar{L}$ is the mean length in the population computed from $L_{\mathrm{c}}$ upward. Here, $L_{\mathrm{c}}$ represents the length at entry into the fishery, assuming knife-edge selection. Using $Z$ equals the sum of fishing $(\mathrm{F})$ and natural $(M)$ mortality, exploitation rate (E) defined as $E=F / Z, M / K$ as the ratio of natural mortality to growth (with values usually between 1 and $3)$, and $E=1-(M / K) /(Z / K)$, we can rearrange eq. 5 to determine $\bar{L}$ as

$$
\begin{array}{r}
\bar{L}=\left[L_{\infty}+\left([(M / K) /(1-E)] L_{c}\right)\right] /([(M / K) / \\
(1-E)]+1)
\end{array}
$$

for $0 \leq E<1$. Based on eq. 4 , the change in TL $(\Delta \mathrm{TL})$ in a fish population where mean body sizes have been reduced by fishing can be estimated from

$$
\Delta \mathrm{TL}=b \log _{10}\left[\frac{L_{\infty}+\left(\left(\frac{M / K}{1-E} L_{\mathrm{c}}\right) /\left(\frac{M / K}{1-E}+1\right)\right)}{L_{\infty}+\left(\left((M / K) L_{c}\right) /((M / K)+1)\right)}\right]
$$

in which all parameters are as defined previously. The estimates of $\Delta \mathrm{TL}$ thus obtained are approximate because the TL values corresponding to a mean length obtained from eq. 7 may differ from the mean TL value of an age-structured population, our next topic.

\section{Age-based relationship between fishing mortality and TL}

An explicit model for estimating the mean TL of an agestructured population in which TL changes linearly with (log) length is

$$
\mathrm{TL}=\frac{\left(\int_{t_{\mathrm{r}}}^{t_{c}} N 1_{t} A \mathrm{~d} t+\int_{t_{\mathrm{c}}}^{t_{\max }} N 2{ }_{t} N 3_{t} A \mathrm{~d} t\right)}{\left(\int_{t_{r}}^{t_{\mathrm{c}}} N 1_{t} \mathrm{~d} t+\int_{t_{\mathrm{c}}}^{t_{\max }} N 2{ }_{t} N 3_{t} \mathrm{~d} t\right)}
$$

where $\mathrm{N} 1_{t}=\mathrm{e}^{-M\left(t-t_{\mathrm{r}}\right)}, \mathrm{N} 2_{t}=\mathrm{e}^{-M\left(t_{c}-t_{r}\right)}, \mathrm{N} 3_{t}=\mathrm{e}^{-F+M\left(t-t_{\mathrm{c}}\right)}, A=3+b$ $\times \log _{10} L_{t}$ (eq. 4$), L_{t}=L_{\infty}\left(1-\mathrm{e}^{-K\left(t-t_{0}\right)}\right)$, i.e., the VBGF for growth in length with parameters $L_{\infty}$ and $K$ as defined above and $t_{0}$ setting the origin of the VBGF, $t_{\mathrm{r}}$ is the recruitment age, i.e., the age from which eq. 8 applies, $t_{\mathrm{c}}$ is the age at entry into the exploited stock, assuming knife-edge selection (i.e., corresponding to $L_{\mathrm{c}}$ ), and $t_{\max }$ is the maximum age in the population.

\section{Fishing mortality trends}

We did not find data from which precise values of fishing mortality could be estimated for all the stocks included in the fisheries statistics described above. However, a time series of $F$, sufficient
Fig. 2. Effects of changing size distributions on estimation of mean TL in Nova Scotian cod in (A) 1971, (B) 1992, and (C) 1999 based on the TL-size relationship for higher-order carnivores in Fig. 1. Note that mean TL changed by $\sim 2 \%$ from 1971 to 1999 compared with $\sim 25 \%$ for mean length and maximum size $\left(L_{\max }\right)$.

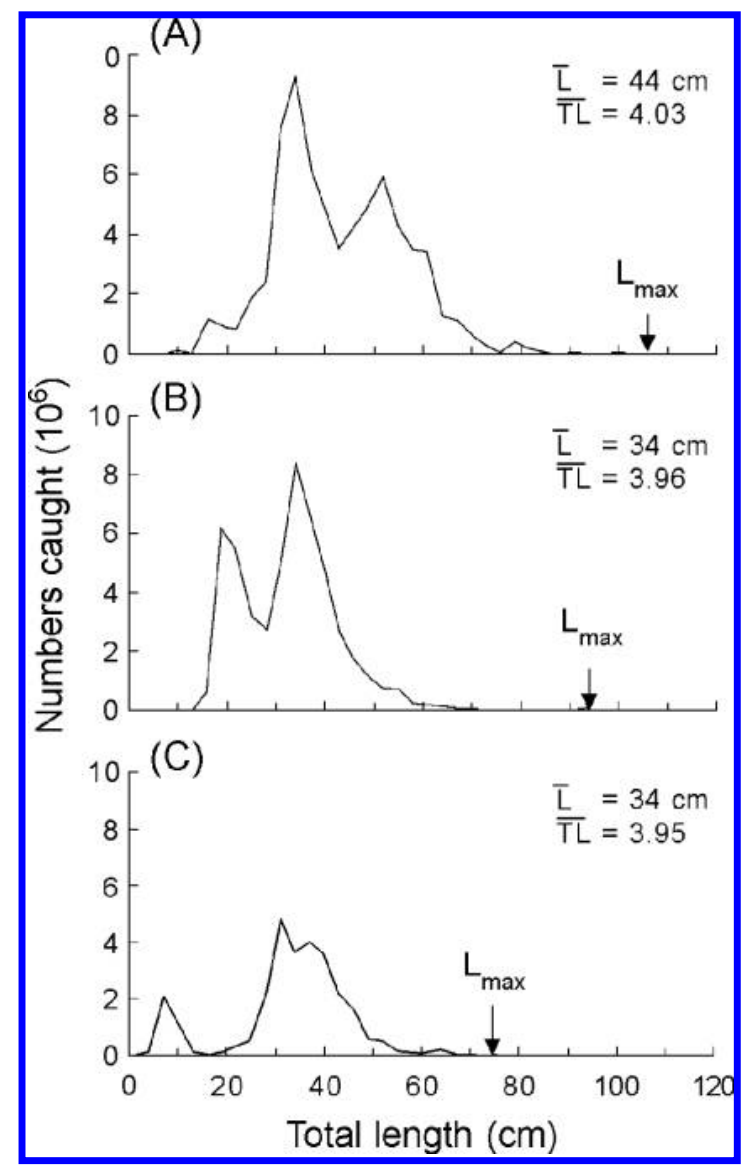

for estimating the potential effect of fishing on size compositions and hence on TL, is available for cod for the entire period covered here (Myers et al. 1995). Estimates of $F$ for other east coast species, although for shorter periods, are also available in the database assembled by Myers et al. (1995), of which an updated version is included in FishBase (Froese and Pauly 1998). We obtained mean values of $F$ by year for each species with suitable data by calculating average $F$ weighted by the landing of each population of that species. These were subsequently grouped into a single estimate for "miscellaneous demersal fishes."

\section{Results}

The basic features of fisheries landings in the three areas considered here are illustrated in Fig. 3. For the east coast (Fig. 3A), overall catch trends were driven by cod landings until the mid- to late 1980s. On the west coast (Fig. 3B), overall catches are highly variable, due to the opening of successive "new" fisheries (marine mammals, Pacific herring (Clupea pallasi), Pacific hake (Merluccius productus)). In contrast, the landing statistics for inland waters (Fig. 3C) do not suggest any long-term trend.

We summarized the TL estimates from FAO statistics for these three areas in the form of catch pyramids to contrast the landings per TL class at the beginning (1950) and end 
Fig. 3. Time series of aggregated fisheries landings from Canadian aquatic ecosystems (see text for sources): (A) east coast, 19501996; (B) west coast, 1873-1996; (C) inland waters, 1917-1997.

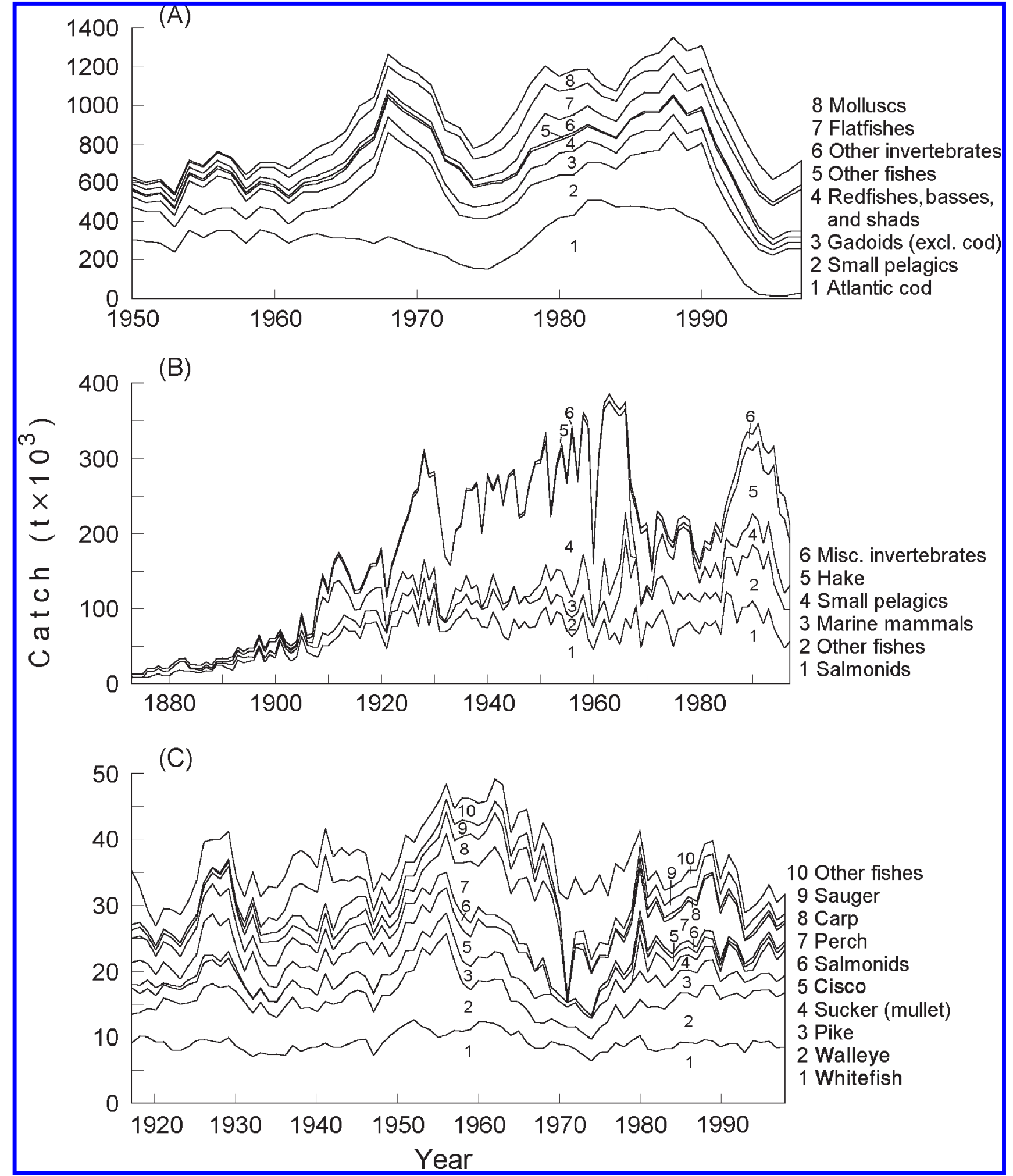

(1997) of the time series. The differences are very large for the east coast (Fig. 4A). The contribution of higher TL fish (especially cod) to the landings has decreased greatly, while that of invertebrates, of which the snow crab (Chionoecetes opilio) is now the most important, has greatly increased. For the west coast (Fig. 4B), the pyramid reflects the important contribution of Pacific herring to the 1950 landings. For inland waters (Fig. 4C), the pyramid represents a small decline in mean TL, from 3.62 in 1950 to 3.45 in 1997, without major shifts in the composition of the landings. However, the 
Fig. 4. "Catch pyramids" representing fisheries landings (open histograms, finfishes; shaded histograms, invertebrates) as a function of their TL (A) on the east coast, (B) on the west coast, and (C) in inland waters. Based on FAO statistics for 1950 (left side of the pyramid) and 1997 (right side) and TL estimates documented in FishBase (which includes a routine for automatic construction of such pyramids for any area with FAO data; Froese and Pauly 1998).

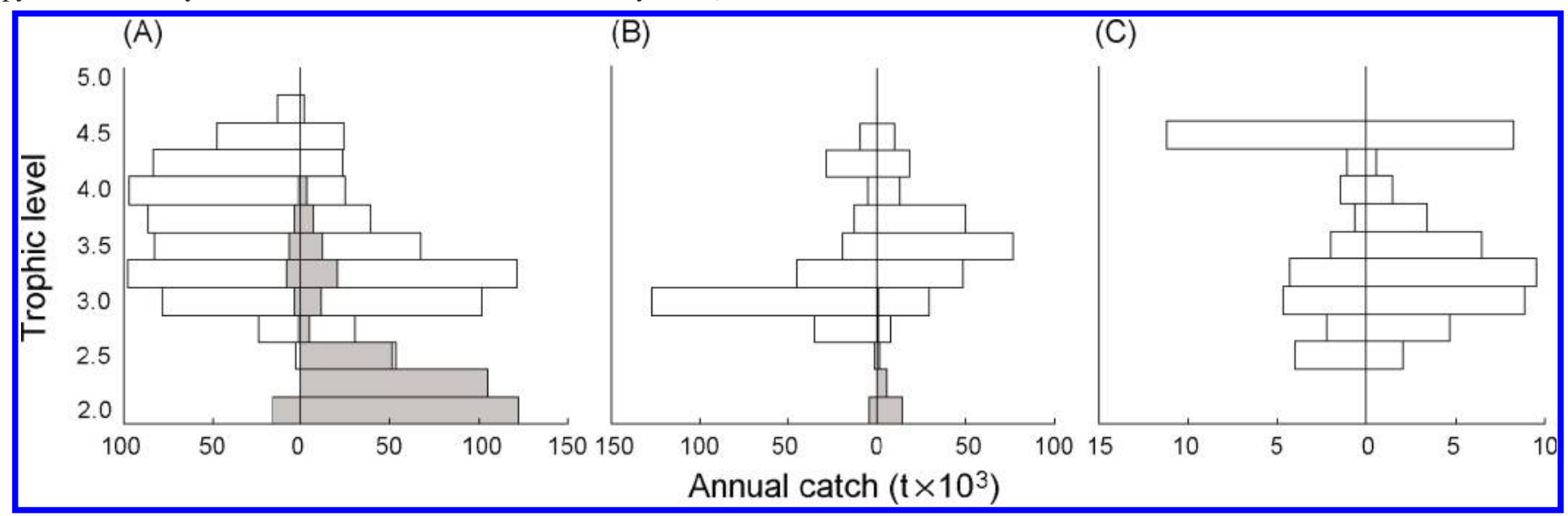

apparent decline is not borne out when longer time series data are used (Fig. 5C).

Trends in the mean TL of organisms in fishery landings for the three areas are illustrated in Fig. 5. There was a marked decline in the east coast fisheries from mean $\mathrm{TL}=$ $3.6-3.7$ in the early 1950 s to $\mathrm{TL}=2.8-2.9$ in the mid-1990s, or about $0.1 \cdot$ decade $^{-1}$ (Fig. 5A). This decline persists if the analysis is made excluding cod, although the rate of mean TL decline is then halved, to about $0.05 \cdot$ decade $^{-1}$.

The trends for the west coast (Fig. 5B) are more complex. The simplest set of piecewise polynomials that fits the data (overall $R=0.50$ ) suggests two periods with different TL trends: a linear increase in mean TL from 1873 to 1894 , with a slope of $0.215 \mathrm{TL} \cdot$ decade $^{-1}$, followed by a period with fluctuating mean TL values and an overall negative TL trend of $-0.032 \cdot$ decade $^{-1}$ (Fig. 5B, inset). Exclusion of Pacific herring leads to a more moderate rate of decline, while exclusion of Pacific hake leads to a steeper rate of decline.

For inland waters, only the FAO data show a downward trend in mean TL (Fig. 5C). The more detailed and longer series of Canadian statistics documented in Table 3 do not confirm the existence of this trend (Fig. 5C). This difference is due, to a large extent, to our criterion of excluding marine fishes taken in estuarine waters. For example, the inclusion of rainbow smelt, which have a low TL (2.5) and relatively high landings (about $10^{4} \mathrm{t}^{-} \mathrm{year}^{-1}$ since the mid-1960s), would have led to a decrease similar to that observed for the FAO data.

Application of our length-based (eq. 7) and age-based model (eq. 8) produced roughly similar results (Fig. 6). Both models predict relatively small decreases in mean TL, except at the very high exploitation rates. However, the models predict that TL will decrease rapidly with increasing $E$ when length at first capture is very small relative to asymptotic length, meaning that the fish are exposed to fishing throughout most of their lives.

Figure 7 documents key aspects of application of our agebased model to the east coast data. Figure 7A shows the available time series of fishing mortality for cod and miscellaneous demersal fishes. Figure 7B illustrates the change in the mean TL of cod given the $F$ values in Fig. 7A, while
Fig. 7C contrasts two series of mean TL for east coast catches, one uncorrected and the other corrected for the within-species effect of $F$-related body size changes on TL.

\section{Discussion}

\section{Mean TL trends in inland waters}

We start our discussion with freshwater ecosystems, as they tend to be small, at least relative to the range of most fishing craft. Human impact on these systems has therefore tended to occur earlier than accounted for by data such as assembled here. For instance, Smith (1995) noted that "Lake Ontario may have had the highest fishery yields of any of the other deepwater Great Lakes, but this occurred before the mid-1800s - before landings began to be recorded. The Atlantic salmon (Salmo salar) was the most-valuable species in the early fishery and was severely depleted before a quantitative account of the fishery could be made."

Thus, the stability suggested by our data for the inland waters of Canada does not preclude earlier anthropogenic changes that may have occurred in these ecosystems. Indeed, human interference, in the form of widespread introductions, has substantially altered the trophic structure of the Great lakes, as reflected, for example, in the relative abundance of coregonines (Fleischer 1992). Also, Pacific salmon, notably chinook (Oncorhynchus tshawytscha) and coho (Oncorhynchus kisutch), were introduced into the Great Lakes in several efforts ranging from hundreds to millions of individuals from the latter part of the nineteenth century up to the end of the twentieth century (Mills et al. 1993). These repeated introductions have resulted in self-reproducing populations that are generally too small to sustain anglers' catches. Hence, there has been the need for continuous restocking through hatchery programs, which, in the case of coho, are responsible for more than $90 \%$ of the total number of adult fish (Crawford 1997).

Our first conclusion, therefore, is that if time series of the mean TL of landed fish are to be useful for analyzing the impact of fisheries, the series must extend far enough into the past to cover major changes in the relative biomass of important ecosystem components. Also, such series must not 
Fig. 5. Time series of mean TLs (weighted by landings) from Canadian aquatic ecosystems: (A) east coast, 1950-1997, with (solid circles) and without cod (open circles); (B) west coast, 1873-1996, with (solid circles) and without Pacific herring (open circles) or Pacific hake (open squares); insert shows fitted piecewise polynomial model and 95\% confidence intervals; (C) inland waters, 19171997, with Canadian (solid circles) and FAO statistics (open circles).

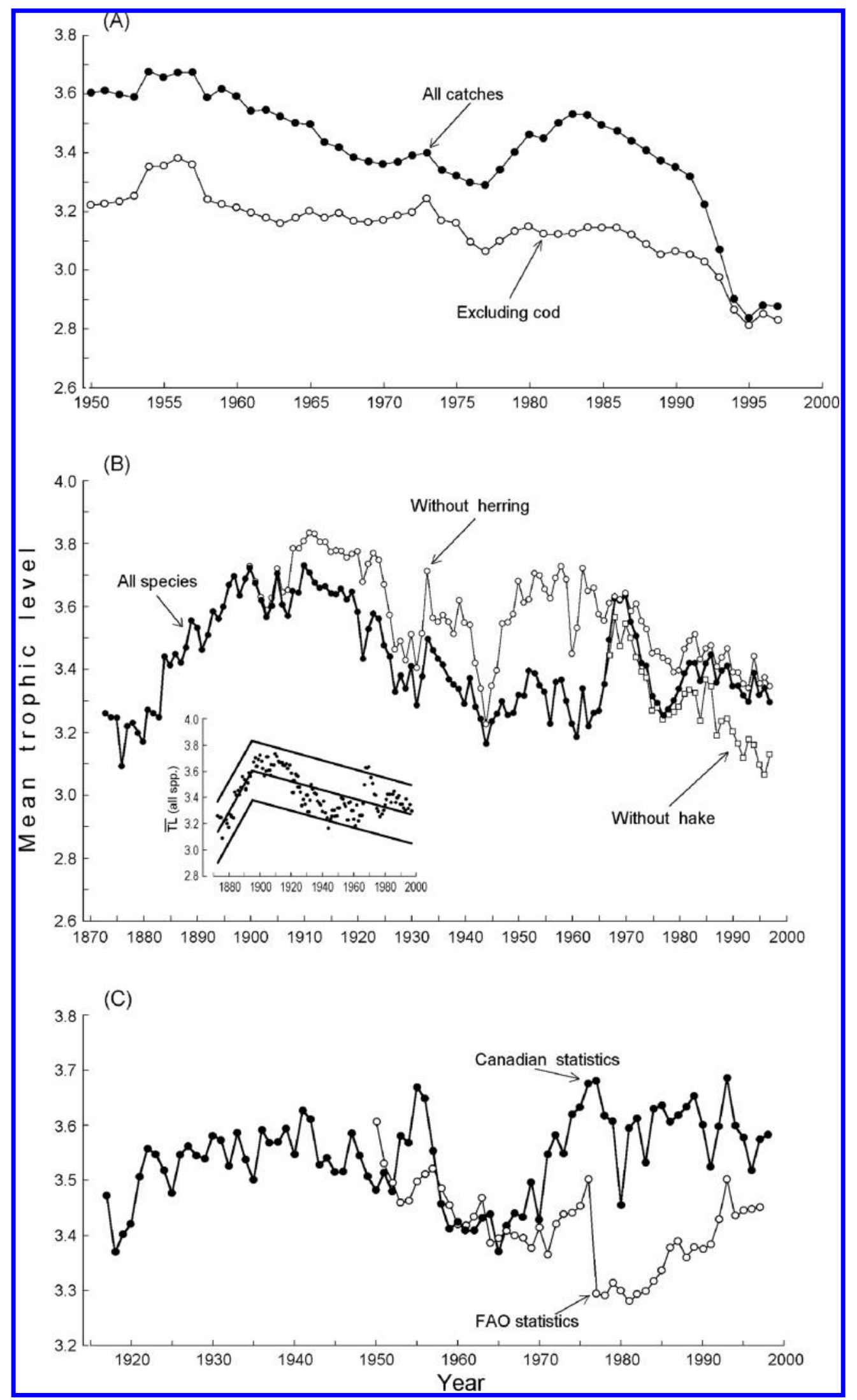


Fig. 6. Nomogram for estimating the effect of fishing (i.e., of $E=F / Z$ ) on the mean TL of a fish population with $M / K=2$ for different values of the ratio $L_{\mathrm{c}} / L_{\infty}$ (see eq. 6 for definitions of $E$ and $M / K$ ). Note that the length-based analysis (broken lines, from eq. 7) provides results roughly similar to those of the age-structured model (solid lines, from eq. 8).

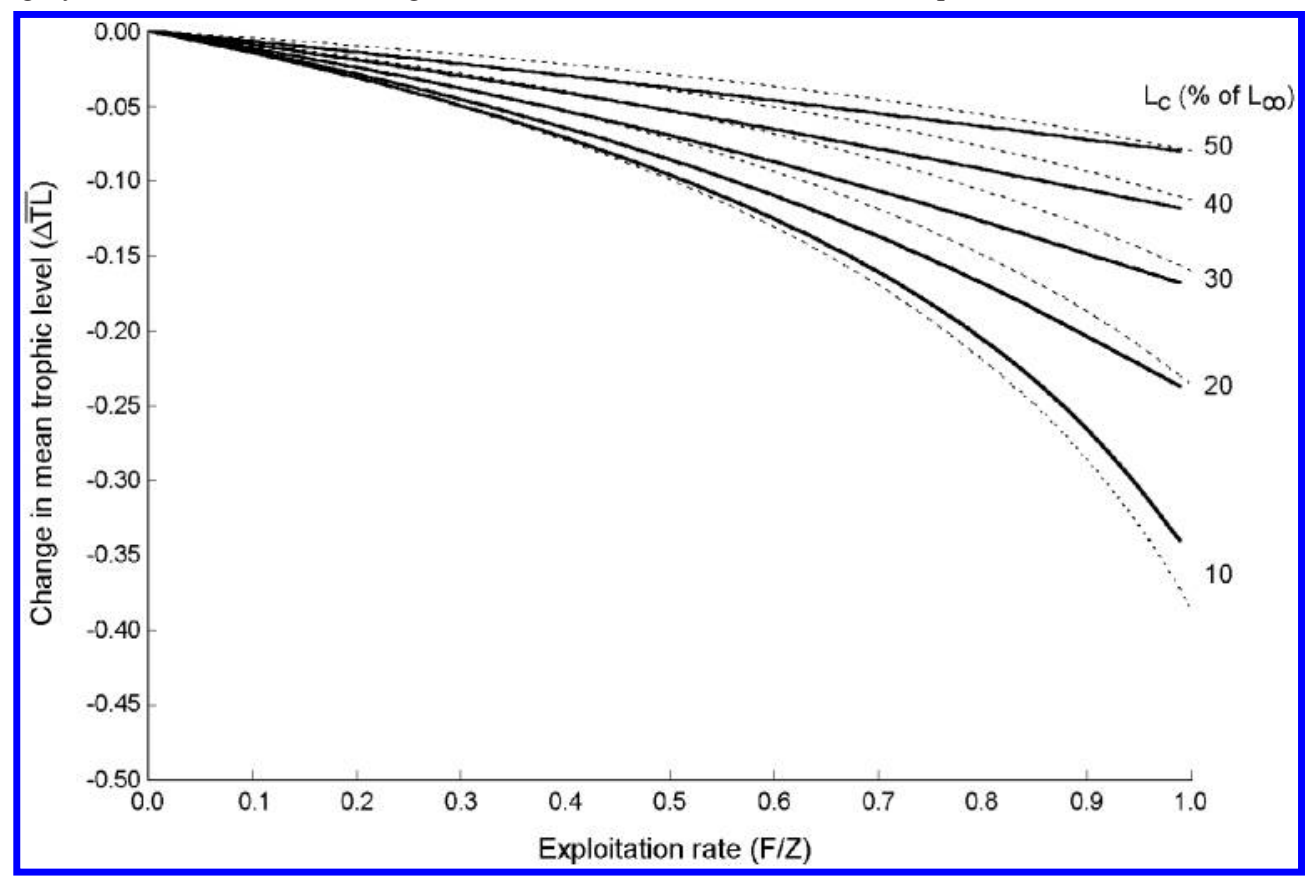

be "contaminated" by anthropogenic impact other than withdrawals by fishing. In the case of Canadian inland waters, the confounding factor is stocking, which maintains relatively high biomass and catches of fishes with high TL (e.g., of Pacific salmon in the Great Lakes), counteracts any "fishingdown" effect, and thus precludes evaluation of sustainability based on mean TL.

\section{Mean TL trends on the east coast}

On the east coast, the operations until the 1970s of distant water fleets and the later deployment of a Canadian trawler fleet had a strongly negative impact on the mean TL of organisms in the landings. The decline in mean TL, while strongly influenced by fluctuations in the cod stock, was shown to occur also when this species is not included in the analysis.

Our new length- and age-based models produced roughly similar estimates of the effect of $F$ on within-species mean TL. The differences between the results from the two models are accounted for by the fact that the length-based model predicts mean TL changes from a single mean length, while the age-based model estimates mean TL as integral of an age-structured population.

The application of the more accurate age-based model to cod and other demersal fishes showed that the within-species effect of size, and hence reduction in TL by fishing, is relatively small, at least when compared with the changes in mean TL due to the fluctuation of a single, abundant species (or its exclusion from the analysis, as shown for cod in the east coast and Pacific herring and Pacific hake in the west coast). This is especially true if the within-species effect involves taxa whose TL does not strongly increase with body size, as is the case for small pelagics (see Fig. 1) and probably for most invertebrates as well.
Overall, given their trend in mean TL, we conclude that the east coast fisheries are unsustainable at the ecosystem level.

\section{Mean TL trends on the west coast}

For the west coast, our results confirm Glavin (1996) who noted that overall landings tend to depend on the status of the latest "new" species. Presently, this new species is $\mathrm{Pa}$ cific hake, and the development of a fishery for this high-TL predator is the reason why the mean TL of organisms in the fisheries is at its present height. Still, in spite of fluctuations caused by this and previous new fisheries (notably that for Pacific herring), the dominant trend in the twentieth century has been one of significant TL decline $\left(-0.032 \cdot\right.$ decade $\left.^{-1}\right)$. The preceding period of increasing TL $\left(0.215 \cdot\right.$ decade $\left.^{-1}\right)$, from 1873 to 1894 , was largely due to the industrialization of the fisheries (formerly dominated by landings of low TL invertebrates), which enabled the catching of previously underexploited, large, high-TL predators (Pacific halibut (Hippoglossus stenolepis), marine mammals, etc.).

The catch pyramid for the west coast confirms the importance of long time series: the comparison of 1950 and 1997 (the period covered in FAO statistics) would suggest that the mean TL of organisms in the west coast fisheries has increased over time. The increase was due to the collapse of fisheries for small pelagics (predominantly Pacific herring), which have low TL, in the 1960s. Given our long time series of mean TL values and their overall trend, we conclude that the west coast fisheries are also unsustainable at the ecosystem level.

\section{General features and uses of mean TL series}

The time series of catches from the marine fisheries off the east and west coasts of Canada have covered sufficiently 
Fig. 7. Relationships between $F$ and mean TL of organisms in Canadian east coast fisheries landings: (A) landings-weighted mean fishing mortality of demersal fishes (thick line, open circles) and of cod (thin line, solid circles) estimated for each year $k$ from $F_{k}^{\prime}=F_{k-4}$ $+2 F_{k-3}+3 F_{k-2}+2 F_{k-1}+F_{k} / 9$ to simulate equilibrium; (B) changes in mean TL of cod predicted by eq. 8 , given the $F_{k}^{\prime}$ values in Fig. 7A and the parameters in Table 1, footnote $f$; (C) original (from Fig. 5A) and corrected time series of mean TL, i.e., considering the effects of cod size reduction, a similar effect on other demersal fishes, and no effect for pelagic fishes and invertebrates.

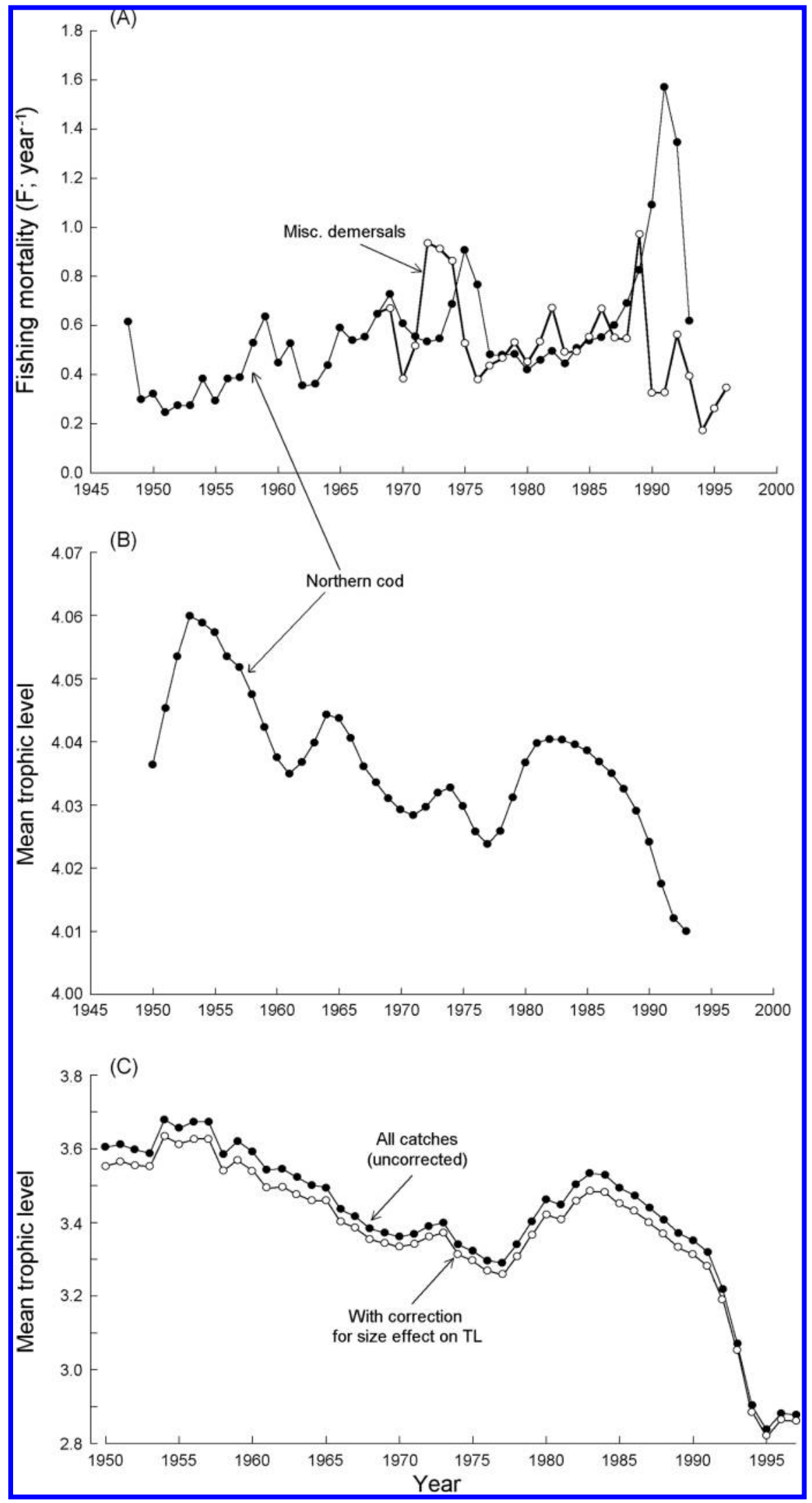


long periods for significant downward trends in the mean TL of the fisheries to appear, thus providing local confirmation of the global trend toward "fishing down marine food webs" documented in Pauly et al. (1998). As pointed out, the time series for inland waters was not adequate for this purpose.

However, it is probably too early to make definite recommendations on how mean TL changes of organisms in landings from a given area could be used to generate precise reference points for ecosystem-based management. Deriving and evaluating potential indices is presently a very active area of fishery and ecosystem research, with consensus on suitable candidates well beyond the horizon. Nevertheless, the present study and the previous analyses by Pauly et al. (1998) allow the identification of diagnostic features that may be considered when such recommendations are made.

(1) An increasing trend in mean TL with increasing or stable total catches may have a number of causes, of which a frequent one is the development of new fisheries for previously unexploited high-TL groups such as offshore and (or) deep-sea species.

(2) Stable mean TL associated with stable total catches suggests sustainability.

(3) a continuous downward trend in mean TL combined with stagnating catches implies absence of sustainability. A continuous downward trend also implies a change in the species mix that is caught, including a transition toward low-TL invertebrates as mean TL drops below 3, the lower limit for non-herbivorous fishes, documenting a fishery now relying strongly on invertebrates.

(4) A decline in mean TL combined with declining catches (including discards) in the absence of change in fished area or gear deployment may imply a food web collapse (possibly the reason for the accelerated mean TL decline in east coast noncod species in the early 1990s), with biological production diverted toward presently unexploited components of the ecosystem such as small benthic invertebrates and (or) jellyfish.

One way to use series of mean TL of organisms in fisheries catches that would combine these four diagnostics and allow drawing inferences on sustainability would be to plot the annual mean TL of "traditional" species (i.e., excluding catches of species not previously exploited) against the corresponding catches (including discards). Given the "pyramidal" nature of marine ecosystems, such plots should exhibit, given sustainability, a straight descending slope reflecting the relationship between biological production and mean TL, i.e., transfer efficiency (Pauly and Christensen 1995). On the other hand, lack of sustainability would lead to departures from linearity and in extreme situations (diagnostic 4) to the "backward-bending" curves of TL versus catch observed by Pauly et al. (1998).

Further, comparisons among mean TL series from similar ecosystems (e.g., around the North Atlantic or the North Pacific) may allow detection of similarities among the mean TL values at which plots of TL versus catches start to bend backward. This in turn may lead to the identification of a generic cutoff point for mean TL, at least for the ecosystem type in question. Obviously, such analyses would have to be conducted repeatedly, with different species groups excluded in order to obtain results unaffected by minor fluctuations in the biomass and catches of individual species.

In any case, the time series used in such analyses should be as long and accurate as possible, lest they induce grossly erroneous interpretations. It was surprising that there was no consistent series of official Canadian catch data. Also, the landing series that may be constructed from official documents and statistics do not match the FAO series based on data supplied to the FAO by the Government of Canada, an FAO member state. Therefore, we cannot but wonder how the detailed assessments of various single-species fisheries routinely conducted in Canada can avoid being marred by the shifting baselines (Pauly 1995) that result from lack of consistent time series that reach well into the past.

\section{Acknowledgments}

We thank Dr. Alida Bundy, DFO, Dartmouth, N.S., for making available data that were then still "in press," Dr. Paul Fanning, DFO, Halifax, N.S., for cod catch at length data and advice, Drs. Tony Pitcher and Villy Christensen for comments on the draft of this contribution, and Mr. Jay Maclean for improving its style. We also thank T. Gagnon, DFO Statistical Services, Ottawa, Ont., and other DFO colleagues for making various data sets available. The first author acknowledges support from the Natural Sciences and Engineering Research Council of Canada and the Pew Charitable Trusts. Dr. M. Lourdes Palomares, Dr. Rainer Froese, Ms. Pascualita Sa-a, and Dr. Michael Vakily are supported by the European Commission (DG VIII) through a grant to the FishBase project.

\section{References}

Argue, A.W., Campbell, D., Gee, P.A., and Shepard, M.P. 1990. Department of Fisheries and Oceans records of annual salmon harvest by British Columbia Indians prior to 1951. Can. Data Rep. Fish. Aquat. Sci. No. 782.

Beverton, R.J.H., and Holt, S.J. 1956. A review of methods for estimating mortality rates in fish populations, with special reference to sources of bias in catch sampling. Rapp. P.-v. Réun. Cons. Int. Explor. Mer, 140: 67-83.

Bigg, M.A. 1969. The harbour seal in British Columbia. Bull. Fish. Res. Board Can. No. 172.

$\checkmark$ Bigg, M.A. 1988. Status of the Seller sea lion, Eumetopias jubatus, in Canada. Can. Field-Nat. 102: 315-336.

Bundy, A., Lily, G., and Shelton, P.A. 2000. A bulk biomass model of the Newfoundland-Labrador shelf. Can. Tech. Rep. Fish. Aquat. Sci. No. 2310.

Caddy, J. 1998. A short review of precautionary reference points and some proposals for their use in data-poor situations. FAO Fish. Tech. Pap. No. 379.

Caddy, J., Csirke, J., Garcia, S.M., and Grainger, R.J.L. 1998. How pervasive is "Fishing down marine food webs". Science (Washington, D.C.), 282: 183. Full text (p. 1383a): <www.sciencemag. org/cgi/content/full/282/5393/1383>

Carrothers, W.A. 1941. The British Columbia fisheries. Political Economy Series 10. University of Toronto Press, Toronto, Ont.

Cass, A.J., Beamish, R.J., and McFarlane, G.A. 1990. Lingcod (Ophiodon elongatus). Can. Spec. Publ. Fish. Aquat. Sci. No. 109. 
Christensen, V., and Pauly, D. 1992. The ECOPATH II — a software for balancing steady-state ecosystem models and calculating network characteristics. Ecol. Model. 61: 169-185.

Cortés, E. 1999. Standardized diet compositions and trophic levels of sharks. ICES J. Mar. Sci. 56: 707-717.

Crawford, S.S. 1997. A review and ecological evaluation of salmonine introductions to the Great Lakes. A report prepared for the Chippewas of Nawash First Nation. <www.uoguelph.ca/ scrawfor/ salmon/salmon.htm>

Culley, M. 1971. The pilchard: biology and exploitation. Pergamon Press, Oxford, U.K.

De Groot, S.J. 1981. On the interrelationships between morphology of the alimentary tract, food and feeding behaviours in flatfishes. Neth. J. Sea Res. 5: 121-196.

-Elner, R., and Campbell, A. 1987. Natural diets of lobster Homarus americanus from barren ground and macroalgal habitats off southwestern Nova Scotia, Canada. Mar. Ecol. Prog. Ser. 37: $131-140$.

Elsey, C.R. 1933. Oysters in British Columbia. Bull. Fish. Res. Board Can. No. 34.

Fisher, H.D. 1952. The status of the harbour seal in British Columbia, with particular reference to the Skeena River. Bull. Fish. Res. Board Can. No. 93.

Fleischer, G.W. 1992. Status of coregonine fishes in the Laurentian Great Lakes. Pol. Arch. Hydrobiol. 39: 247-259.

Froese, R., and Pauly, D. (Editors). 1998. FishBase 98: concepts, structure and data sources. International Center for Living Aquatic Resources Management, Manila, Philippines. Updates: <www.fishbase.org>

Glavin, T. 1996. Dead reckoning: confronting the crisis of Pacific fisheries. Greystone Books, Vancouver, B.C.

Hart, J.L., and McHugh, J.L. 1944. The smelts (Osmeridae) of British Columbia. Bull. Fish. Res. Board Can. No. 64.

Hewes, G.W. 1973. Indian fisheries productivity in pre-contact times in the Pacific salmon area. Northwest Anthropol. Res. Notes, 7: 133-155.

Hintze, J.L. 1998. User's guide. NCSS 2000 statistical system for Windows. Number Cruncher Statistical Systems, Kaysville, Utah.

Hourston, A.S. 1980. The decline and recovery of Canada's Pacific herring stocks. Rapp. P.-v. Réun. Cons. Int. Explor. Mer, 177: 143-153.

Jefferson, T.A., Leatherwood, S., and Webber, M.A. 1993. Marine mammals of the world. FAO Species Identification Guides, Rome.

Jennings, S., Reynold, J.D., and Mills, S.C. 1997. Life history correlates of response to fisheries exploitation. Proc. R. Soc. Lond. Ser. B, Biol. Sci. 265: 333-339.

Ketchen, K.S. 1986. The spiny dogfish (Squalus acanthias) in the Northeast Pacific and a history of its utilization. Can. Spec. Publ. Fish. Aquat. Sci. No. 88.

Kirkwood, G.P., Beddington, J.R., and Rossouw, J.A. 1994. Harvesting species of different lifespans. In Large-scale ecology and conservation biology. Edited by P.J. Edwards, R.M. May, and N.R. Webb. Blackwell Scientific Publications, Oxford, U.K. pp. 199-227.
Kline, T.C., Jr., and Pauly, D. 1998. Cross-validation of trophic level estimates from a mass-balance model of Prince William Sound using ${ }^{15} \mathrm{~N} /{ }^{14} \mathrm{~N}$ data. In Proceedings of the International Symposium on Fishery Stock Assessment Models. Edited by T.J. Quinn II, F. Funk, J. Heifetz, J.N. Ianelli, J.E. Powers, J.F. Schweigert, P.J. Sullivan, and C.-I. Zhang. Alaska Sea Grant College Program Rep. No. 98-01. Alaska Sea Grant, Fairbanks, Alaska.

May, A.W., Pinhorn, A.T., Wells, R., and Fleming, A.M. 1965. Cod growth and temperature in the Newfoundland area. In Environmental Symposium. Int. Comm. Northwest Atl. Fish. Spec. Publ. No. 6: $545-555$.

Mills, E.L., Leach, J.H., Carlton, J.T., and Secor, C.L. 1993. Exotic species in the Great Lakes: a history of biotic crises and anthropogenic introductions. J. Gt. Lakes Res. 19: 1-54.

-Myers, R.A., and Doyle, R.W. 1983. Predicting natural mortality rates and reproduction-mortality trade offs from fish life history data. Can. J. Fish. Aquat. Sci. 40: 612-620.

Myers, R.A., Bridson, J., and Barrowman, N.J. 1995. Summary of worldwide stock and recruitment data. Can. Tech. Rep. Fish Aquat. Sci. No. 2024.

National Research Council. 1999. Sustaining marine fisheries. National Research Council. National Academy Press, Washington, D.C.

Parsons, T.R. 1996. The impact of industrial fisheries on the trophic structure of marine ecosystems. In Food webs: integration of patterns and dynamics. Chap. 33. Edited by G.A. Polis and K.D. Winnemiller. Chapman and Hall, New York. pp. 352-357.

Pauly, D. 1995. Anecdotes and the shifting baseline syndrome of fisheries. Trends Ecol. Evol. 10: 430.

- Pauly, D., and Christensen, V. 1995. Primary production required to sustain global fisheries. Nature (Lond.), 374: 255-257.

Pauly, D., Christensen,V., Dalsgaard, J., Froese, R., and Torres, F.C., Jr. 1998. Fishing down marine food webs. Science (Washington, D.C.), 279: 860-863.

Pike, G.C., and MacAski, I.B. 1969. Marine mammals of B.C. Bull. Fish. Res. Board Can. No. 171.

Pinhorn, A.T. 1975. Estimates of natural mortality for the cod stock complex in ICNAF Divisions $2 \mathrm{~J}, 3 \mathrm{~K}$ and $3 \mathrm{~L}$. Int. Comm. Northwest Atl. Fish. Res. Bull. 11: 31-36.

Schusterman, R.J. 1981. Steller sea lion - Eumetopias jubatus. In Handbook of marine mammals. Vol. 1. Edited by S.M. Ridgway and R.J. Harrison. Academic Press, New York. pp. 119-141.

Shepard, M.P., and Argue, A.W. 1989. The commercial harvest of salmon in British Columbia, 1820-1877. Can. Tech. Rep. Fish. Aquat. Sci. No. 690.

Shepard, M.P., Shepard, C.D., and Argue, A.W. 1985. Historic statistics of salmon production around the Pacific Rim. Can. Manuscr. Rep. Fish. Aquat. Sci. No. 1819.

Smith, S.H. 1995. Early changes in the fish community of Lake Ontario. Great Lakes Fish. Comm. Tech. Rep. No. 60.

Stocker, M. 1994. Groundfish stock assessments for the west coast of Canada in 1993 and recommended yield options for 1994. Can. Tech. Rep. Fish. Aquat. Sci. No. 1975.

-Wieczorek, S.K., and Hooper, R.G. 1995. Relationship between diet and food availability in the snow crab Chionoecetes opilio (O. fabricius) in Bonne Bay, Newfoundland. J. Crustacean Biol. 15: $236-247$. 


\section{This article has been cited by:}

1. Margarida Hermida, João Delgado. 2016. High trophic level and low diversity: Would Madeira benefit from fishing down?. Marine Policy 73, 130-137. [CrossRef]

2. Paul M. Tuda, Matthias Wolff, Annette Breckwoldt. 2016. Size structure and gear selectivity of target species in the multispecies multigear fishery of the Kenyan South Coast. Ocean \& Coastal Management 130, 95-106. [CrossRef]

3. Jianguo Du, Xinqing Zheng, Teguh Peristiwady, Jianji Liao, Petrus Ch. Makatipu, Xijie Yin, Wenjia Hu, Wulan Koagouw, Bin Chen. 2016. Food sources and trophic structure of fishes and benthic macroinvertebrates in a tropical seagrass meadow revealed by stable isotope analysis. Marine Biology Research 12:7, 748-757. [CrossRef]

4. MELINDA A. COLEMAN, TIM INGLETON, RUSSELL B. MILLAR, PETER L. DAVIES, ALAN JORDAN, BRENDA P. KELAHER. 2016. Remotely sensed habitat variables are poor surrogates for functional traits of rocky reef fish assemblages. Environmental Conservation 1-8. [CrossRef]

5. Qi Ding, Xinjun Chen, Wei Yu, Siquan Tian, Yong Chen. 2016. An evaluation of underlying mechanisms for "fishing down marine food webs". Acta Oceanologica Sinica 35:8, 32-38. [CrossRef]

6. Friedrich Wolfgang Keppeler, Gustavo Hallwass, Renato Azevedo Matias Silvano. 2016. Influence of protected areas on fish assemblages and fisheries in a large tropical river. Oryx 1-12. [CrossRef]

7. Marzieh Razzaghi, Sakineh Mashjoor, Ehsan Kamrani. 2016. Mean trophic level of coastal fisheries landings in the Persian Gulf (Hormuzgan Province), 2002-2011. Chinese Journal of Oceanology and Limnology . [CrossRef]

8. Philippe Cury, Arnaud Bertrand, Sophie Bertrand, Marta Coll, Philippe Gros, Souad Kifani, François Le Loch, Olivier Maury, Frédéric Menard, Florent Renaud, Lynn Shannon, Yunne-Jai Shin 221. [CrossRef]

9. Sakineh Mashjoor, Ehsan Kamrani. 2015. Evaluation of the "fishing down marine food web" process in the north-west of Persian Gulf (Khuzestan Province) during the period of 2002-2011. Acta Oceanologica Sinica 34, 103-110. [CrossRef]

10. M Colléter, CJ Walters, P Gatti, D Gascuel. 2015. Including foraging arena and top-down controls improves the modeling of trophic flows and fishing impacts in aquatic food webs. Marine Ecology Progress Series 534, 17-37. [CrossRef]

11. M. A. Coleman, A. E. Bates, R. D. Stuart-Smith, H. A. Malcolm, D. Harasti, A. Jordan, N. A. Knott, G. J. Edgar, B. P. Kelaher. 2015. Functional traits reveal early responses in marine reserves following protection from fishing. Diversity and Distributions 21:10.1111/ddi.2015.21.issue-8, 876-887. [CrossRef]

12. Jianguo Du, William W.L. Cheung, Guanqiong Ye, Qiulin Zhou, Bin Chen. 2015. Impacts of fishing on the marine mean trophic level in Chinese marine area. Acta Ecologica Sinica 35, 83-88. [CrossRef]

13. Sangdeok Chung, Hirokazu Suzaki, Akihide Kasai, Hideaki Nakata. 2015. The Response of Fish Communities to Climate and Human-Induced Changes Inferred from Fishery Landings in an Enclosed Bay. Estuaries and Coasts 38, 1365-1375. [CrossRef]

14. Robyn E. Forrest, Marie Savina, Elizabeth A. Fulton, Tony J. Pitcher. 2015. Do marine ecosystem models give consistent policy evaluations? A comparison of Atlantis and Ecosim. Fisheries Research 167, 293-312. [CrossRef]

15. Jennifer M. Marsh, Robert J. Foy, Nicola Hillgruber, Gordon H. Kruse. 2015. Variability in trophic positions of four commercially important groundfish species in the Gulf of Alaska. Fisheries Research 165, 100-114. [CrossRef]

16. Paul M. Tuda, Matthias Wolff. 2015. Evolving trends in the Kenyan artisanal reef fishery and its implications for fisheries management. Ocean \& Coastal Management 104, 36-44. [CrossRef]

17. Purusothaman Sambandamoorthy, Jayaprabha Nagamuthu, Silambarasan Arumugam, Murugesan Perumal. 2015. Diversity and trophic level of ichthyofauna associated with the trawl bycatches of Cuddalore and Parangipettai, south-east coast of India. Marine Biodiversity Records 8. . [CrossRef]

18. Kara Stevens, Brian Irwin, Daniel Kramer, Gerald Urquhart. 2014. Impact of increasing market access on a tropical small-scale fishery. Marine Policy 50, 46-52. [CrossRef]

19. L Shannon, M Coll, A Bundy, D Gascuel, JJ Heymans, K Kleisner, CP Lynam, C Piroddi, J Tam, M Travers-Trolet, Y Shin. 2014. Trophic level-based indicators to track fishing impacts across marine ecosystems. Marine Ecology Progress Series 512, 115-140. [CrossRef]

20. K Kleisner, H Mansour, D Pauly. 2014. Region-based MTI: resolving geographic expansion in the Marine Trophic Index. Marine Ecology Progress Series 512, 185-199. [CrossRef]

21. Ines Gomes, Karim Erzini, Timothy R. McClanahan. 2014. Trap modification opens new gates to achieve sustainable coral reef fisheries. Aquatic Conservation: Marine and Freshwater Ecosystems 24:10.1002/aqc.v24.5, 680-695. [CrossRef] 
22. Cosmas N. Munga, Johnstone O. Omukoto, Edward N. Kimani, Ann Vanreusel. 2014. Propulsion-gear-based characterisation of artisanal fisheries in the Malindi-Ungwana Bay, Kenya and its use for fisheries management. Ocean \& Coastal Management 98, 130-139. [CrossRef]

23. Thomas A. Okey, Hussein M. Alidina, Veronica Lo, Sabine Jessen. 2014. Effects of climate change on Canada's Pacific marine ecosystems: a summary of scientific knowledge. Reviews in Fish Biology and Fisheries 24, 519-559. [CrossRef]

24. O. Riche, S.C. Johannessen, R.W. Macdonald. 2014. Why timing matters in a coastal sea: Trends, variability and tipping points in the Strait of Georgia, Canada. Journal of Marine Systems 131, 36-53. [CrossRef]

25. I. McKechnie, D. Lepofsky, M. L. Moss, V. L. Butler, T. J. Orchard, G. Coupland, F. Foster, M. Caldwell, K. Lertzman. 2014. Archaeological data provide alternative hypotheses on Pacific herring (Clupea pallasii) distribution, abundance, and variability. Proceedings of the National Academy of Sciences . [CrossRef]

26. C.-N. Tsai, W.-C. Chiang, C.-L. Sun, K.-T. Shao, S.-Y. Chen, S.-Z. Yeh. 2014. Trophic size-structure of sailfish Istiophorus platypterus in eastern Taiwan estimated by stable isotope analysis. Journal of Fish Biology 84:10.1111/jfb.2014.84.issue-2, 354-371. [CrossRef]

27. Heidi K. Alleway, Sean D. Connell, Tim M. Ward, Bronwyn M. Gillanders. 2014. Historical changes in mean trophic level of southern Australian fisheries. Marine and Freshwater Research 65, 884. [CrossRef]

28. Y. Letourneur, T. Lison de Loma, P. Richard, M. L. Harmelin-Vivien, P. Cresson, D. Banaru, M.-F. Fontaine, T. Gref, S. Planes. 2013. Identifying carbon sources and trophic position of coral reef fishes using diet and stable isotope $(\delta 15 \mathrm{~N}$ and $\delta 13 \mathrm{C})$ analyses in two contrasted bays in Moorea, French Polynesia. Coral Reefs 32, 1091-1102. [CrossRef]

29. Hector Lozano-Montes, Neil R. Loneragan, Russ Babcock, Nick Caputi. 2013. Evaluating the ecosystem effects of variation in recruitment and fishing effort in the western rock lobster fishery. Fisheries Research 145, 128-135. [CrossRef]

30. Dave Preikshot, Richard J. Beamish, Chrys M. Neville. 2013. A dynamic model describing ecosystem-level changes in the Strait of Georgia from 1960 to 2010. Progress in Oceanography 115, 28-40. [CrossRef]

31. J. E. Perez Comesaña, P. Clavin, K. Arias, C. Riestra. 2013. Total length estimation of the Brazilian flathead Percophis brasiliensis, using morphometric relationships of skull, pectoral girdle bones, otoliths and specific body measures, in Argentine waters. Journal of Applied Ichthyology n/a-n/a. [CrossRef]

32. Syazana Ebil, Charles R.C. Sheppard, Ranimah Wahab, Andrew R.G. Price, James C. Bull. 2013. Changes in community structure of finfish catches in Brunei Darussalam between 2000 and 2009. Ocean \& Coastal Management 76, 45-51. [CrossRef]

33. S. J. Campbell, A. Mukminin, T. Kartawijaya, C. Huchery, J. E. Cinner. 2013. Changes in a coral reef fishery along a gradient of fishing pressure in an Indonesian marine protected area. Aquatic Conservation: Marine and Freshwater Ecosystems n/a-n/a. [CrossRef]

34. Emily Ruth Hardman, Alasdair James Edwards, Jean Stephen Jovani Raffin. 2013. The seine-net fishery of Rodrigues Island, western Indian Ocean: Is it sustainable or in terminal decline?. Fisheries Research 139, 35-42. [CrossRef]

35. C.M.R. Foley. 2013. Management implications of fishing up, down, or through the marine food web. Marine Policy 37, 176-182. [CrossRef]

36. Louis Legendre, Nathalie Niquil. 2013. Large-scale regional comparisons of ecosystem processes: Methods and approaches. Journal of Marine Systems 109-110, 4-21. [CrossRef]

37. Min Zhang, Congxin Xie, Lars-Anders Hansson, Wanming Hu, Jiapu Che. 2012. Trophic level changes of fishery catches in Lake Chaohu, Anhui Province, China: Trends and causes. Fisheries Research 131-133, 15-20. [CrossRef]

38. Daniel Nyitrai, Filipe Martinho, Marina Dolbeth, Joana Baptista, Miguel A. Pardal. 2012. Trends in estuarine fish assemblages facing different environmental conditions: combining diversity with functional attributes. Aquatic Ecology 46, 201-214. [CrossRef]

39. L. Gasche, D. Gascuel, L. Shannon, Y.-J. Shin. 2012. Global assessment of the fishing impacts on the Southern Benguela ecosystem using an EcoTroph modelling approach. Journal of Marine Systems 90, 1-12. [CrossRef]

40. TIMOTHY R. McClANAHAN, JOHNSTONE O. OMUKOTO. 2011. Comparison of Modern and Historical Fish Catches (AD 750-1400) to Inform Goals for Marine Protected Areas and Sustainable Fisheries. Conservation Biology 25, 945-955. [CrossRef]

41. Mohamed Ali Jerbi, Zouhour Ouanes, Raouf Besbes, Lotfi Achour, Adnen Kacem. 2011. Single and combined genotoxic and cytotoxic effects of two xenobiotics widely used in intensive aquaculture. Mutation Research/Genetic Toxicology and Environmental Mutagenesis 724, 22-27. [CrossRef]

42. D. Gascuel, S. Guenette, D. Pauly. 2011. The trophic-level-based ecosystem modelling approach: theoretical overview and practical uses. ICES Journal of Marine Science 68, 1403-1416. [CrossRef] 
43. Djibril Faye, Luis Tito de Morais, Jean Raffray, Oumar Sadio, Omar Thiom Thiaw, François Le Loc'h. 2011. Structure and seasonal variability of fish food webs in an estuarine tropical marine protected area (Senegal): Evidence from stable isotope analysis. Estuarine, Coastal and Shelf Science 92, 607-617. [CrossRef]

44. André S. Afonso, Fábio H.V. Hazin, Felipe Carvalho, José C. Pacheco, Humberto Hazin, David W. Kerstetter, Debra Murie, George H. Burgess. 2011. Fishing gear modifications to reduce elasmobranch mortality in pelagic and bottom longline fisheries off Northeast Brazil. Fisheries Research 108, 336-343. [CrossRef]

45. R. G.FarmerR.G. Farmer, M. L.LeonardM.L. Leonard. 2011. Long-term feeding ecology of Great Black-backed Gulls (Larus marinus) in the northwest Atlantic: 110 years of feather isotope data. Canadian Journal of Zoology 89:2, 123-133. [Abstract] [Full Text] [PDF] [PDF Plus]

46. R.B.M. Pincinato, M.A. Gasalla. 2010. Priceless prices and marine food webs: Long-term patterns of change and fishing impacts in the South Brazil Bight as reflected by the seafood market. Progress in Oceanography 87, 320-330. [CrossRef]

47. Kátia M.F. Freire, Daniel Pauly. 2010. Fishing down Brazilian marine food webs, with emphasis on the east Brazil large marine ecosystem. Fisheries Research 105, 57-62. [CrossRef]

48. K.P. Abdurahiman, T.H. Nayak, P.U. Zacharia, K.S. Mohamed. 2010. Trophic organisation and predator-prey interactions among commercially exploited demersal finfishes in the coastal waters of the southeastern Arabian Sea. Estuarine, Coastal and Shelf Science 87, 601-610. [CrossRef]

49. Joseph E. Powers, Melissa H. Monk. 2010. Current and future use of indicators for ecosystem based fisheries management. Marine Policy 34, 723-727. [CrossRef]

50. J.M. Ecoutin, M. Simier, J.J. Albaret, R. Laë, L. Tito de Morais. 2010. Changes over a decade in fish assemblages exposed to both environmental and fishing constraints in the Sine Saloum estuary (Senegal). Estuarine, Coastal and Shelf Science 87, 284-292. [CrossRef]

51. Benjamin R. Knight, Weimin Jiang. 2009. Assessing primary production constraints in New Zealand fisheries. Fisheries Research 100, 15-25. [CrossRef]

52. Estelle Jones, Tim Gray, Chanin Umponstira. 2009. The impact of artisanal fishing on coral reef fish health in Hat Thai Mueang, Phang-nga Province, Southern Thailand. Marine Policy 33, 544-552. [CrossRef]

53. Filipa Baeta, Maria José Costa, Henrique Cabral. 2009. Changes in the trophic level of Portuguese landings and fish market price variation in the last decades. Fisheries Research 97, 216-222. [CrossRef]

54. Michael A.LitzowM.A. Litzow, DanielUrbanD. Urban. 2009. Fishing through (and up) Alaskan food webs. Canadian Journal of Fisheries and Aquatic Sciences 66:2, 201-211. [Abstract] [Full Text] [PDF] [PDF Plus]

55. Iain C. Field, Mark G. Meekan, Rik C. Buckworth, Corey J.A. BradshawChapter 4 Susceptibility of Sharks, Rays and Chimaeras to Global Extinction 275-363. [CrossRef]

56. Sean C.AndersonS.C. Anderson, Heike K.LotzeH.K. Lotze, Nancy L.ShackellN.L. Shackell. 2008. Evaluating the knowledge base for expanding low-trophic-level fisheries in Atlantic Canada. Canadian Journal of Fisheries and Aquatic Sciences 65:12, 2553-2571. [Abstract] [Full Text] [PDF] [PDF Plus]

57. Brajgeet Bhathal, Daniel Pauly. 2008. 'Fishing down marine food webs' and spatial expansion of coastal fisheries in India, 19502000. Fisheries Research 91, 26-34. [CrossRef]

58. M.L. Tonks, S.P. Griffiths, D.S. Heales, D.T. Brewer, Q. Dell. 2008. Species composition and temporal variation of prawn trawl bycatch in the Joseph Bonaparte Gulf, northwestern Australia. Fisheries Research 89, 276-293. [CrossRef]

59. K. de Mutsert, J. H. Cowan, T. E. Essington, R. Hilborn. 2008. Reanalyses of Gulf of Mexico fisheries data: Landings can be misleading in assessments of fisheries and fisheries ecosystems. Proceedings of the National Academy of Sciences 105, 2740-2744. [CrossRef]

60. David M. Post, Martin W. Doyle, John L. Sabo, Jacques C. Finlay. 2007. The problem of boundaries in defining ecosystems: A potential landmine for uniting geomorphology and ecology. Geomorphology 89, 111-126. [CrossRef]

61. Qisheng Tang, Xuewu Guo, Yao Sun, Bo Zhang. 2007. Ecological conversion efficiency and its influencers in twelve species of fish in the Yellow Sea Ecosystem. Journal of Marine Systems 67, 282-291. [CrossRef]

62. B. Zhang, Q. Tang, X. Jin. 2007. Decadal-scale variations of trophic levels at high trophic levels in the Yellow Sea and the Bohai Sea ecosystem. Journal of Marine Systems 67, 304-311. [CrossRef]

63. Antonio Bode, M. Teresa Alvarez-Ossorio, M. Emilia Cunha, Susana Garrido, J. Benito Peleteiro, Carmela Porteiro, Luis Valdés, Manuel Varela. 2007. Stable nitrogen isotope studies of the pelagic food web on the Atlantic shelf of the Iberian Peninsula. Progress in Oceanography 74, 115-131. [CrossRef] 
64. Horacio Pérez-España, Luis G. Abarca-Arenas, María de Lourdes Jiménez-Badillo. 2007. Reply: The absence of "fishing-down food web" does not mean a healthy fishery. Fisheries Research 85, 235-236. [CrossRef]

65. Octavio Aburto-Oropeza, Luis G. López-Lemus, Gustavo Paredes, Miriam Reza, Andrea Sáenz-Arroyo, Enric Sala. 2007. Fisheries Research 85, 233-234. [CrossRef]

66. Brian N. Popp, Brittany S. Graham, Robert J. Olson, Cecelia C.S. Hannides, Michael J. Lott, Gladis A. López-Ibarra, Felipe Galván-Magaña, Brian FryInsight into the Trophic Ecology of Yellowfin Tuna, Thunnus albacares, from Compound-Specific Nitrogen Isotope Analysis of Proteinaceous Amino Acids 173-190. [CrossRef]

67. Brian N. Popp, Brittany S. Graham, Robert J. Olson, Cecelia C.S. Hannides, Michael J. Lott, Gladis A. López-Ibarra, Felipe Galván-Magaña, Brian FryInsight into the Trophic Ecology of Yellowfin Tuna, Thunnus albacares, from Compound-Specific Nitrogen Isotope Analysis of Proteinaceous Amino Acids 173-190. [CrossRef]

68. Morgane Travers, Yunne-Jai Shin, Lynne Shannon, Philippe Cury. 2006. Simulating and testing the sensitivity of ecosystembased indicators to fishing in the southern Benguela ecosystem. Canadian Journal of Fisheries and Aquatic Sciences 63:4, 943-956. [Abstract] [PDF] [PDF Plus]

69. T. E. Essington. 2006. Fishing through marine food webs. Proceedings of the National Academy of Sciences 103, 3171-3175. [CrossRef]

70. Yongjun Tian, Hideaki Kidokoro, Tatsuro Watanabe. 2006. Long-term changes in the fish community structure from the Tsushima warm current region of the Japan/East Sea with an emphasis on the impacts of fishing and climate regime shift over the last four decades. Progress in Oceanography 68, 217-237. [CrossRef]

71. Andrés C. Milessi, Hugo Arancibia, Sergio Neira, Omar Defeo. 2005. The mean trophic level of Uruguayan landings during the period 1990-2001. Fisheries Research 74, 223-231. [CrossRef]

72. Alida Bundy. 2005. Structure and functioning of the eastern Scotian Shelf ecosystem before and after the collapse of groundfish stocks in the early 1990s. Canadian Journal of Fisheries and Aquatic Sciences 62:7, 1453-1473. [Abstract] [PDF] [PDF Plus]

73. Søren A. Pedersen, Mads H. Ribergaard, Claus S. Simonsen. 2005. Micro- and mesozooplankton in Southwest Greenland waters in relation to environmental factors. Journal of Marine Systems 56, 85-112. [CrossRef]

74. R.W. Macdonald, T. Harner, J. Fyfe. 2005. Recent climate change in the Arctic and its impact on contaminant pathways and interpretation of temporal trend data. Science of The Total Environment 342, 5-86. [CrossRef]

75. Simone Libralato, Fabio Pranovi, Saša Raicevich, Filippo Da Ponte, Otello Giovanardi, Roberto Pastres, Patrizia Torricelli, Danilo Mainardi. 2004. Ecological stages of the Venice Lagoon analysed using landing time series data. Journal of Marine Systems 51, 331-344. [CrossRef]

76. J F Caddy. 2004. Current usage of fisheries indicators and reference points, and their potential application to management of fisheries for marine invertebrates. Canadian Journal of Fisheries and Aquatic Sciences 61:8, 1307-1324. [Abstract] [PDF] [PDF Plus]

77. R. Arlinghaus, T. Mehner, I. G. CowxNachhaltige Binnenfischerei: Reconciling traditional inland fisheries management and sustainability in industrialized countries, with emphasis on Europe 1-44. [CrossRef]

78. Dirk Zeller, Garry R. Russ. 2004. Are fisheries 'sustainable'? A counterpoint to Steele and Hoagland. Fisheries Research 67, 241-245. [CrossRef]

79. Robie W Macdonald, Brian Morton, Sophia C Johannessen. 2003. A review of marine environmental contaminant issues in the North Pacific: The dangers and how to identify them. Environmental Reviews 11:2, 103-139. [Abstract] [PDF] [PDF Plus]

80. Cindy Chu, Charles K Minns, Nicholas E Mandrak. 2003. Comparative regional assessment of factors impacting freshwater fish biodiversity in Canada. Canadian Journal of Fisheries and Aquatic Sciences 60:5, 624-634. [Abstract] [PDF] [PDF Plus]

81. Martin Willison. 2002. Science and policy for marine sanctuaries. Biodiversity 3, 15-20. [CrossRef]

82. K.C.T. Zwanenburg, D. Bowen, A. Bundy, K. Frank, K. Drinkwater, R. O'Boyle, D. Sameoto, M. Sinclair4 Decadal changes in the Scotian Shelf large marine ecosystem 105-150. [CrossRef] 